\title{
TIME REQUIRED AND SUCCESS RATE OF PERCUTANEOUS RIGHT ATRIAL CATHETERIZATION: DESCRIPTION OF A TECHNIQUE
}

\author{
Roy F. Cucchiara, Joseph M. Messick, Gerald G. Gronert and John D. Michenfelder
}

\section{Abstract}

The use of an intracardiac catheter is considered useful in the diagnosis of air embolism during surgical operations.

Under electrocardiographic (ECG) control a right atrial catheter was placed through the right antecubital (basilic) vein in 200 patients undergoing posterior fossa or cervical operations in the sitting position. The overall success rate for this technique was 97 per cent. Half were successfully placed within five minutes, and 92 per cent within 15 minutes.

AN INTRACARDIAC CATHETER is considered useful in the diagnosis of air embolism during surgical operations. This paper presents a method for consistent placement of a right atrial catheter without undue delay of the surgical procedure.

\section{METHOD}

A right atrial catheter was placed in 200 patients undergoing posterior fossa or cervical operation in the sitting position. A timer was started and a 14-gauge teflon needle $\left(\mathrm{Jelco}^{(\mathrm{P})}\right.$ ) was placed in the medial right antecubital (basilic) vein immediately after induction of anaesthesia. A 36inch polyethylene (B-D No. 7521) catheter was passed through the needle and attached through a Tuohy-Borst adapter (B-D No. 3097-610A) and a saline-filled syringe to an isolated $V$ lead of the electrocardiogram. The catheter was advanced under electrocardiographic (ECG) control until characteristic P-wave changes occurred (Figure 1). Catheterization was considered successful only if the ECG and the turbulence detection test ${ }^{\text {t }}$ were mutually confirmatory.

\section{RESULTS}

The overall success rate for right atrial catheter placement was 97 per cent. The right arm was used for introduction of the catheter in 184 of the 200 patients with 178 successes. In ten patients the right arm was unsuitable for venipuncture and another site was used. Half ( 53 per cent) of the catheters were placed successfully within five

Roy F. Cucchiara, M.D., Joseph M. Messick, M.D., Gerald G. Gronert, M.D., and John D. Michenfelder, M.D., Consultants in Anaesthesiology, Mayo Clinic, Rochester, Minnesota, 55901 U.S.A. 572

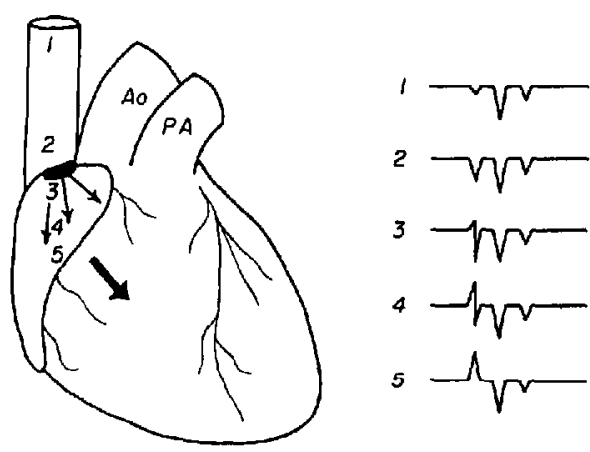

FIGURE I Stylized electrocardiographic tracings from the catheter tip in various locations. Note progressive P-wave changes. The P-wave is initially negative and small (1). As the catheter tip approaches the atrium the P-wave becomes progressively more negative (2) When the tip enters the atrium a small positive deflection can be seen (3). The P-wave is large and biphasic in midatrium (4) and indicates proper catheter position. A large positive P-wave indicates low atrial placement of the catheter (5)

TABLE I

Time Required to Place Right Atrial Catheter (Minutes)

\begin{tabular}{lcrrr}
\hline & $\leq 5$ & $6-15$ & $>15$ & Total \\
\hline Successful & 106 & 77 & 12 & 195 \\
Unsuccessful & & 1 & 4 & 5 \\
Total & 106 & 78 & 16 & 200 \\
\hline
\end{tabular}

minutes and 92 per cent were placed within 15 minutes (Table I).

\section{Discussion}

There is no doubt that the right atrial catheter can aspirate air which enters the venous system 
during neurosurgical operations in the sitting position. ${ }^{2}$ The right atrial catheter is generally, although not completely, accepted as useful in the diagnosis and treatment of such air embolism. ${ }^{3-5}$ In part, reluctance to use an intracardiac catheter in these situations is due to difficult and time-consuming experiences in their placement. Techniques for increasing the success rate of central venous catheterizations have been examined. ${ }^{6}$ Their highest success rate for unmonitored central venous catheterization was 98 per cent (49/50 placements) with a Sorensen catheter. Our success rate of 97 per cent in 200 cases is comparable, with the added advantage of precise knowledge of the location of the tip of the catheter.

\section{CONCLUSION}

The placement of this catheter system by ECG control was consistent, fairly rapid and not unduly difficult once experience was gained in reading the ECG changes. The technique allows catheter placement in the operating room without significant delay of the operative procedure.

\section{REFERENCES}

1. Tinker, J.H., Gronert, G.A., Messick, J.M. et al. Detection of air embolism, a test for positioning of right atrial catheter and Doppler probe. Anesthesiology 43: 104-106 (1975).

2. MiCHENFELDER, J.D. MARTIN, J.T, ALTEN BURG, B.M., et ul. Air embolism during neurosurgery: an evaluation of right atrial catheters for diagnosis and treatment. J.A.M.A. 708: $1353-1358$ (1969).

3. JACKSON, P.L. Intracardiac catheters unnecessary in neurosurgical anesthesia. Anesthesiology 48: 154(1978)

4. MUNSON, E.S. Intracardiac catheters in neurosurgical anesthesia. Anesthesiology 50:67 (1979).

5. ALBIN, M.S. Ibid.

6. Bridges, B.B., Carden, E. \& Takacs, F. Introduction of central venous pressure catheters through arm veins with a high success rate. Canad. Anaesth. Soc. J. 26: 128-131 (1979).

\section{Résumé}

L'utilisation d'un cathéter intracardiaque est considérée une méthode utile pour diagnostiquer les embolies aériennes en cours de chirurgie. Les auteurs ont placé un cathéter dans l'oreillette droite de deux cents patients soumis à une chirurgie de la fosse postérieurc ou de la colonne cervicale en position assise. Les cathéters étaient glissés à travers une aiguille de teflon Jelco \#14 dans la veine basilique droite et positionnés dans l'oreillette droite sous contrôle électrocardiographique (le cathéter étant relié à un appareil d'électrocardiographie). Cette méthode a permis d'obtenir un taux de succès de 97 pour cent. La moitié des cathéters ont été mis en place en moins de cinq minutes, et 92 pour cent en moins de 15 minutes. 